\title{
Production of Bioethanol From Kappaphycus alvarezii Algae by Using Pichia kudriavzevii
}

\author{
Nurfadillah, Winda Lestari Taufan, Muhammad Syahdan Aska \& Sulfahri \\ Department of Biology, Faculty of Mathematics and Natural Sciences, Hasanuddin \\ University, Makassar, Indonesia
}

\begin{abstract}
Kappaphycus alvarezii is a red algae that can be used as alternative raw material for bioethanol production. This is because $K$. alvarezii contains a high carbohydrate that reaches $60 \%$. This study aims to determine the effect of fermentation nutrition and fermentation duration of hydrolysis results of $K$. alvarezii algae on $\mathrm{pH}$ changes, sugar levels, cell biomass and ethanol content. There are two methods was used in this research, namely hydrolysis method and fermentation method. The hydrolysis method was used $\alpha$-amylases enzyme which is $150 \mathrm{KNU} / \mathrm{L}$ with $0.5 \%, 1.0 \%, 1.5 \%$ and $2.0 \%$ concentrations. The next method, K. alvarezii algae was fermented by Pichia kudriavzevii and used Gandasil- $D^{\circledR}$ as an anorganic suplementation and yeast extract which is $0 \mathrm{~g} / \mathrm{L}, 1 \mathrm{~g} / \mathrm{L}, 2 \mathrm{~g} / \mathrm{L}$ and $3 \mathrm{~g} / \mathrm{L}$. The results showed that $K$. alvarezii can be fermented into bioethanol after enzymatic hydrolysis process. The optimal ethanol content was produced at 48 hours of incubation duration.
\end{abstract}

\section{Article History}

Received 06 June 2018

Accepted 12 July 2017

Keyword

Hydrolysis

Fermentation

$\alpha$-amylases

Phicia kudriavzevii

\section{Introduction}

$K$. alvarezii is a leading commodity produced in various countries, one of that is Indonesia whose production reaches 12-18 tons of dry algae/ha/ year (Hayashi et al., 2011; Lee et al., 2016; Ra et al., 2013) . This algae was contains protein, fiber and carbohydrates (Ra et al., 2013; Fayaz et al., 2005). Carbohydrate content of polysaccharide reaches $60.6 \%$ which consists of kappa-carrageenan and cellulose (Ra et al., 2013; Kim et al., 2015; Arad \& Levy-Ontman, 2010). These carbohydrates can be broken down into monosugar through a hydrolysis process and will be fermented to produced etanol (Kim et al., 2015; Gonzalez et al., 2008; Ravanal et al., 2016; Munoz et al., 2004).

Bioethanol is an organic compound with the chemical formula $\mathrm{C}_{2} \mathrm{H}_{5} \mathrm{OH}$ that resulting from the fermentation process of starches, sugars and cellulose with the help of certain microorganisms (Kumar et al., 2013; Sankh et al., 2013). Bioethanol production was developed as fuel replacement fuel with fuel grade ethanol $\geq 99.5 \%$ to compensate for the scarcity of petroleum resources. It can be an alternative energy because the oxygen content 
was high, environmentally friendly, and its energy source was can reneweble (Kumar et al., 2013; Madigan et al., 2012).

Bioethanol produced from biomass is usually produced by biochemical processes such as fermentation process. Biomass which is used as raw material of bioethanol is corn and sugar cane where the raw material is a food material and it takes a large area to produce it. The existence of microalgae is very potential in the production of bioethanol to replace raw materials that still have high food value. Microalgae contains carbohydrates and proteins that can be used as a carbon source in the fermentation process of bioethanol formation (Nicolau et al., 2010).

Enzymatic hydrolysis and fermentation process are effective in breaking cellulose and hemicellulose present in marine algae into sugar (Gonzales et al., 2008; Ravanal et al., 2016). Carbohydrate hydrolysis can be performed by using enzymes such as cellulase to hydrolyze cellulose, while to hydrolysis of hemicellulose can use enzymes such as glucuronidase, acetyl esterase, xylanase, $\beta$-xylosidase, galactomannanase, glucomannanase and $\alpha$-amylase enzymes used to hydrolyze the kappa-carrageenan (Ramachandran et al., 2013; Wu et al., 2014). Kappa-carrageenan is a hydrocolloid composed of D-galactose-4sulphate and 3,6-anhydro-D-galactose-2-sulfate which are potentially fermentable to obtain bioethanol from the fermentation process (Loreo et al., 2013; Chang et al., 2017; Meinita et al., 2012; Fayaz et al., 2005).

Another method that can be used is fermentation. One of the potential microbes in the fermentation process is Pichia kudriavzevii. P. kudriavzevii is one of the yeast that is round, elliptical or elongated (Pandey et al., 2000). Previous studies have shown that P. kudriavzevii contains $29.3 \%$ palmitate, $8.89 \%$ stearate and oleic acid $41.9 \%$. This yeast can also be used as a mixed starter culture on combinations between ethanol-tolerant (Nicolau et al., 2010; Ra et al., 2013). Therefore, this study aims to determine the effect of fermentation nutrition and fermentation duration of $\mathrm{K}$. alvarezii algae hydrolysis results on $\mathrm{pH}$ change, sugar levels, cell biomass and ethanol content.

\section{Materials and Methods}

\section{Kapppaphycus alvarezii}

This study used the marien algae of $K$. alvarezii obtained from coastal waters of Punaga village, Mangarabombang District, Takalar regency. Algae that have been obtained are then identified that belong to $K$. alvarezii type.

\section{Pretreatment Kappaphycus alvarezii Algae}

Algae biomass washed and soaked in clean water for 2-3 hours. Then dried under the sun. Algae K. alvarezii that has been dried mashed using a hummer mill and sifted using a 40 mesh sieve. The resulting algae flour was weighed according to a combination of concentrations are $0.5 \% ; 1 \% ; 1.5 \%$ and $2 \%$, then dissolved with $50 \mathrm{~mL}$ distilled water.

\section{Hydrolysis Kappaphycus alvarezii Algae}

K. alvarezii algae solution with variation concentration of $0.5 \%, 1.0 \%, 1.5 \%$, and 2.0\%. Then, the algae solution was heated using a hot plate at $100{ }^{\circ} \mathrm{C}$ for 90 minutes. Thereafter, an enzyme $\alpha$-amylase of $80 \mathrm{KNU} / \mathrm{L}$ was added. The added solution of the incubated apparatus for 24 hours, 48 hours and 72 hours. Once hydrolyzed, the algae solution is filtered to separate the natan and its supernatant. The supernatant was then 
centrifuged at $9,000 \mathrm{rpm}$ for $10 \mathrm{~min}$. Supernatant of centrifugation was taken and measured its sugar content.

\section{Fermentation Process}

K. alvarezii solution was prepared according to the optimal concentration obtained at the hydrolysis process, which is $0.5 \%$ with the addition of $150 \mathrm{KNU} / \mathrm{L}$ enzyme $\alpha$-amylase and incubated for 24 hours. Then, fermentation method was added nutrients in form of Gandasil- ${ }^{\circledR}$ as an inorganic nutrient and Yeast Extract as an organic nutrition $(0.5 \mathrm{~g} / \mathrm{L}$ and $1.0 \mathrm{~g} / \mathrm{L}$ ). After that, a starter $P$. kudriavzevi was activated with $5 \%$ concentration into the fermentor bottle. The fermentation process are used various fermentation durations $(0$ hours, 24 hours, 48 hours and 72 hours). After the incubation period of 0 hours, 24 hours, 48 hours and 72 hours, measurements of sugar levels, ethanol content and cell biomass of P. kudriavzevii.

\section{Measurement of Cell Biomass}

The cellular biomass of $P$. kudriavzevii was measured using the method of dry cell weight ( $D C W=$ dry cell weight). The dry weight of the cell was carried out by first centrifuging the fermentation medium sample by $50 \mathrm{~mL}$ at 9,000 rpm for $10 \mathrm{~min}$. After centrifugation, supernatant and pellet cells are obtained. The supernatant is removed by pipette. After that, the resulting pellets are then washed by adding aquadest on the cell pellets and centrifuged at 9,000 rpm for $5 \mathrm{~min}$. The pellet is then suspended with aquadest and vacuumed with a pipette and then transferred into a filter paper with a pore size of 0.47 $\mu \mathrm{m}$ which has previously been diovened to a constant weight (W1). The filter paper containing pellets is then dried in the oven at $80^{\circ} \mathrm{C}$ for 24 hours and weighed (W2). The DCW result is the difference between the weight of the final filter paper and the weight of the initial filter paper (W2-W1) expressed by the dry weight of the cell with gram/liter (g/L) unit.

\section{Data Analysis}

This study used RAL (Complete Random Design) with three replications. The parameters measured were sugar content and cell biomass. Data were analyzed statistically using Analysis of Variance (Anova) with 95\% confidence interval ( $\alpha=0.05$ ). The analysis was conducted to compare the effect of acid hydrolysis process on sugar content and fermentation process effect in yielding sugar content and cell biomass from algae K. alvarezii. If there is influence then continued with Tukey test at 95\% confidence level $(\alpha=$ 0.05 ) to know pair of group the same and different data in each treatment.

\section{Results and discussion}

\section{Sugar Levels in Hydrolysis Process}

The results of the measurement of sugar content showed that algae concentration of $0.5 \%$ resulted in average sugar content of $0.56 \mathrm{~g} / \mathrm{g}$ during 24 and 48 hours incubation. While, 72 hour incubation showed the average of different sugar content with other incubation duration, that is $0,47 \mathrm{~g} / \mathrm{g}$. Then concentration of $1 \%$ yields, mean sugar content of $0.56 \mathrm{~g} / \mathrm{g}$ at 24 hours and 48 hours incubation. While, the duration of incubation 72 hours resulted in the average of sugar content of $0.46 \mathrm{~g} / \mathrm{g}$ the concentration of $1.5 \%$ on 24 hours, 48 hours and 72 hours incubation time resulted in average sugar content of $0.46 \mathrm{~g} / \mathrm{g}$. Whereas at $2 \%$ concentration yield average of sugar content equal to $0,49 \mathrm{~g} / \mathrm{g}$ during incubation period 24 hours, 48 hours and 72 hours. 
Based on ANOVA test at $95 \%$ confidence interval it can be seen that the concentration of $\mathrm{K}$. alvarezii algae used has significant effect on sugar content, but the duration of incubation does not affect the sugar content, then continued with Tukey test. Then, from the Tukey test it was concluded that the most optimum sugar content produced was at a concentration of $0.5 \%$ and $1 \%$ marine algae with an incubation period of 24 hours, 48 hours and 72 hours. Therefore, researchers used $0.5 \%$ concentration with 24 hours incubation duration.

Table 2. Comparison of Sugar Result from this Study with Several References Related Research in Hydrolysis Process

\begin{tabular}{|c|c|c|c|c|c|c|}
\hline \multirow{2}{*}{ Marine Algae } & \multicolumn{4}{|c|}{ Treatment } & \multirow{2}{*}{$\begin{array}{l}\text { Sugar } \\
(\mathrm{g} / \mathrm{g})\end{array}$} & \multirow{2}{*}{ Reff } \\
\hline & Enzyme & Temp & pH & Time & & \\
\hline $\begin{array}{l}\text { Laminaria } \\
\text { digitata }\end{array}$ & Cellulose & $37^{\circ} \mathrm{C}$ & 5 & 24 jam & 0.09 & $\begin{array}{c}\text { Vanegas et } \\
\text { al.,2015 }\end{array}$ \\
\hline $\begin{array}{l}\text { Saccarina } \\
\text { latissima }\end{array}$ & Cellulose & $37^{\circ} \mathrm{C}$ & 5 & 24 jam & 0.12 & $\begin{array}{c}\text { Vanegas et } \\
\text { al.,2015 }\end{array}$ \\
\hline Gelidium amansii & Cellulose & $40^{\circ} \mathrm{C}$ & 5 & 48 jam & 0.13 & $\begin{array}{c}\text { Ra et al., } \\
2012\end{array}$ \\
\hline $\begin{array}{l}\text { Saccarina } \\
\text { japonica }\end{array}$ & $\alpha$-amylase & $45^{\circ} \mathrm{C}$ & 5 & 60 menit & 0.2 & $\begin{array}{l}\text { Jang et al., } \\
2012\end{array}$ \\
\hline $\begin{array}{l}\text { Entheromorpha } \\
\text { intestinalis }\end{array}$ & $\begin{array}{c}\text { Viscozyme }{ }^{\oplus} \\
\text { \& Cellic } \\
\text { CTec } 2\end{array}$ & $45^{\circ} \mathrm{C}$ & 5 & 48 jam & 0.2 & $\begin{array}{c}\text { Kim et } \\
\text { al.,2015 }\end{array}$ \\
\hline Gracillaria sp. & Cellulose & $50^{\circ} \mathrm{C}$ & 4.5 & 6 jam & 0.3 & $\begin{array}{c}\text { Wu et al., } \\
2014\end{array}$ \\
\hline $\begin{array}{c}\text { Kappaphycus } \\
\text { alvarezii }\end{array}$ & $\alpha$-amilase & $40^{\circ} \mathrm{C}$ & 5 & 24 jam & 0.56 & $\begin{array}{c}\text { Penelitian } \\
\text { ini }\end{array}$ \\
\hline
\end{tabular}

Research used enzymatic hydrolysis method yields sugar of $0.3 \mathrm{~g} / \mathrm{g}$ of Gracillaria sp. Marine algae (Wu et al., 2014). While Gelidium amansii only produced a sugar content of $0.13 \mathrm{~g} / \mathrm{g}$ (Ra et al., 2013) and a similar study was performed using Entheromorpha intestinalis marine algae producing a sugar content of $0.21 \mathrm{~g} / \mathrm{g}$ (Wu et al., 2014). More study by used Saccarina latissima just able to produce $0.12 \mathrm{~g} / \mathrm{g}$ sugar and Laminaria digitata produce sugar levels of $0.09 \mathrm{~g} / \mathrm{g}$ (Vanegas et al., 2015). While, in other studies produced sugar content of $0.2 \mathrm{~g} / \mathrm{g}$ by using the enzyme $\alpha$-amylase and algae Saccarina japonica as raw materials (Jang et al., 2012).

Based on the comparison of some references, it is known that the lowest sugar content is obtained from research using Laminaria digitata algae that is $0,09 \mathrm{~g} / \mathrm{g}$ and reference with highest sugar content from Gracillaria sp. of $0.31 \mathrm{~g} / \mathrm{g}$ of sugar content (Vanegas et al., 2015 and Wu et al., 2014). So from the comparison, it can be said that research using $K$. alvarezii algae, proved higher in producing sugar content of $0.56 \mathrm{~g} / \mathrm{g}$. K. alvarezii has a greater chance of producing bioethanol from the resulting sugar content.

\section{Sugar and Ethanol Levels in Fermentation Process}

This fermentation process is done during 24 hour interval, 48 hours and 72 hours. The results showed that the sugar content will decrease with the length of fermentation time and ethanol content will increasingly with the lenght the fermentation time. This means that polysaccharides contained in the algae of $K$. alvarezii algae produce high sugar 
levels at the beginning of fermentation but because of the use of $P$. kudriavzevii yeast causes reduced sugar content of yeast to produce ethanol. Based on previous research who said that light will be consumed by the microbes at the beginning of the fermentation period (Wu et al., 2014). The resulting ethanol content also reaches the optimum level.

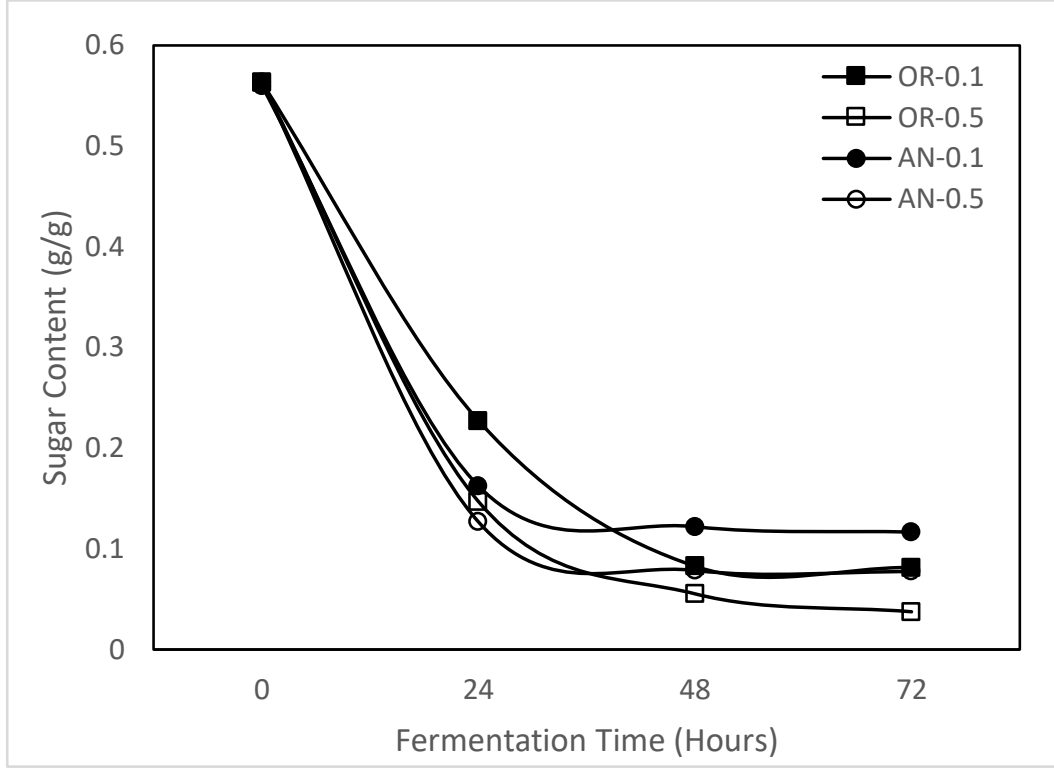

Figure 1. Average Graph of Fermented Sugar Level with P. Kudriavzevii

Based on ANOVA test at $95 \%$ confidence interval it can be estimated that nutritional distance of nutrients and fermentation concentration did not significantly influence to ethanol content. So it can be concluded that the most optimal sugar content produced at hours 0 hours with sugar content of $0.56 \pm 0.06 \mathrm{~g} / \mathrm{g}$ while ethanol content is most generated at 48 hours incubation and ethanol content of $0.28 \pm 0.50 \mathrm{~g} / \mathrm{g}$. This proves that yeast $P$. kudriavzevii by using the algae of $\mathrm{K}$. alvarezii algae which has greater potential in producing bioethanol.

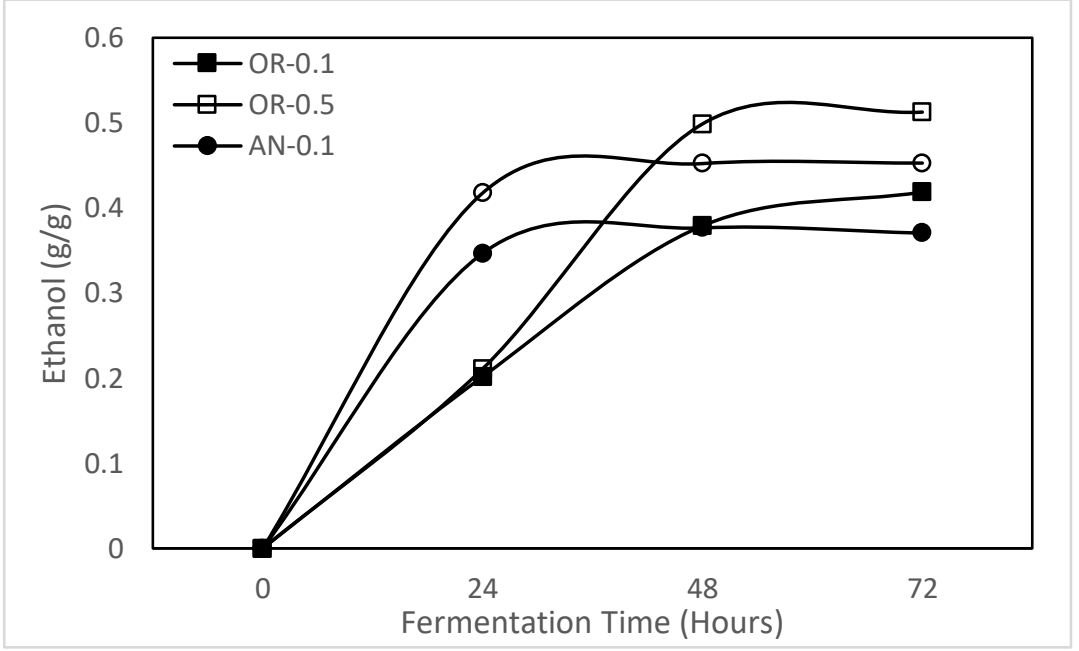

Figure 2. Graph of Average Ethanol Levels with Inorganic Nutrition (Gandasil-D ${ }^{\circledR}$ ) and Organic (Yeast Ekstract) During Fermentation Process 


\section{Biomass Levels in Fermentation Procces}

The success of fermentation can be seen based on the microbial growth response on the fermentation medium. In this study, the measurement of yeast cell biomass $P$. kudriavzevii was done by using dry weight method (dry cell weight). Cell biomass measurements were performed during fermentation of 0 hours, 24 hours, 48 hours and 72 hours.

The results showed that the longer of fermentation duration so the more cell biomass produced. This means that yeast P. kudriavzevii has used carbohydrates from the algae medium to divide. Based on the research of Widodo et al. (2013) explains that the fermentation time is very influential on the activity of yeast because the longer the fermentation so the more active yeast breeding.

Based on the ANOVA test at a 95\% confidence interval it can provide different values of fermented nutrients or unconverted fermented concentration to the biomass of fermentation time cells affecting the resulting cell biomass. The biomass that produces fermented nutrients does not differ significantly with inorganic supplementation and the use of producing similar biomass. It was concluded that most biomass was produced at 48 hours incubation and yielded cell biomass of $0.27 \pm 0.003 \mathrm{~g} / \mathrm{g}$.

\section{Conclusions}

The enzymatic hydrolysis process yields the most optimum sugar content whic is $0.56 \mathrm{~g} / \mathrm{g}$ at $0.5 \%$ algae concentration. Meanwhile, the use of yeast $P$. kudriavzevii in the fermentation process yields a sugar content which is $0.56 \pm 0.06 \mathrm{~g} / \mathrm{g}$ and ethanol content of $0.28 \pm 0.50 \mathrm{~g} / \mathrm{g}$ at 48 hours incubation duration.

\section{Acknowledgment}

The authors gratefully acknowledge financial support from the Ministry of Research, Technology and Higher Education of Indonesia with project PKM (Program Kreativitas mahasiswa).

\section{References}

Arad, S.M., Levy-Ontman, O. 2010. Red Microalgal Cell-Wall Polysaccharides: Biotechnological Aspects. Curr.Opin.Biotechnol. 21 (3): 358-364.

Chang, V., Patrick, N. O., Swee-Sen, T. 2017. The Properties Of Red Seaweed (Kappaphycus Alvarezii) And Its Effect On Mammary Carcinogenesis. Biomedicine \& Pharmacotherapy. 296-301.

Del Monaco, S.M., Maria E. Rodriguez, Chistian A. Lopes. 2016. Pichia kudriavzevii as a Representative yeast of North Patagonian Winemaking Terrior. Journal International of Food Microbiology. 230: 31-39.

Fayaz, M., K.K. Namitha, K.N. Chidambara Murthy, M. Mahadeva Swamy, R. Sarada, S. Khanam, P.V. Subbarao, G.A. Ravishankar. 2005. Chemical composition iron bioavailability, and antioxidant activity of K. alvarezii (Doty). Journal Agriculture Food Chem. 53: 792-797.

Gonzalez, C.F., Farina, J.I. \& Figueroa, L.I.C. 2008.Optimized Amylolytic Enzymes Production in S. fibuligera DSM-70554.Enzyme and Microbial Technology. 42: 272-277. 
Hayashi, L., A.A. Santos, G.S.M. Faria, B.G. Nunes, M.S. Souza, A.L.D. Fonseca, P.L. M. Barreto, E.C. Oliveira, Z.L. Bouzon. 2011. K. alvarezii(Rhodophyta, Areschougiaceae) cultivated in subtropical waters in Southern Brazil. J. App. Phys. 23: 337-343.

Jang, J.S., Cho, Y.K., Jeong, G.T., Kim, S.K., 2012a. Optimization of saccharification andethanol production by simultaneous saccharification and fermentation (SSF)from seaweed, Saccharina japonica. Bioprocess Biosyst. Eng. 35, 11-18.Jannah, A., M. 2010.Proses Fermentasi Hidrolisat Jerami Padi Untuk Menghasilkan Bioetanol.Jurnal Teknik Kimia. 17(1): 44.

Kim, S.W., Hong, C., Jeon, S. \& Shin, H. 2015. High-yield Production of Biosugars from Gracilaria verrucosa by Acid and Enzymatic Hydrolysis Processes. Bioresource Technology. 196: 634-641.

Kumar, S., Gupta, R., Kumar, G., Sahoo, D., Kuhad, R.C., 2013.Bioethanol productionfrom Gracilaria verrucosa, a red alga, in a biorefinery approach.Bioresour.Technol. 135: 150156.

Lee, Sang-Bum and Gwi, T. J. 2016.Production of Biosugar from Red Macro-Algae Eucheuma cottonii Using Acid-Hydrolysis.Microbiolgy and Biotechnology Letters. 44(1): 48-54.

Loreo, Y. C., Ferrari, M. D., Guigo, M., Fajardo, L., Larnaudie, V., Ramirez, M. B. \& Gerreiro, J. M. 2013.Evaluation of Sweet Potato for Fuel Bioethanol Production: Hydrolysis and Fermentation. Springer Plus. (2): 1-11.

Meinita, M. D. N., Ji-Young, K., Gwi-Taek, J., Hyun, M. K., Sung, M. P., Yong-Ki, H. 2012. Bioethanol Production from the Acid Hydrolysate of the Carrageenophyte Kappaphycus alvarezii (cottonii). Journal of Applied Phycology. 24(4): 857-862.

Munoz, J., Y. Freile-Pelegrin, D. Robledo. 2004. Mariculture of K. alvarezii(Rhodophyta, Solieriaceae) Color Strains in Tropical Waters of Yucatan, Mexico. Agriculture. 239, 161177.

Nicolau, A., Georgescu, L. \& Bolocan, A. 2010. Impact Of Bioprocessing On Rice. Food Technology. 35(1) 19-26.

Pandey, A., Nigam, P., et al. 2000. Advances in microbial amylases.Biotechnol. Appl. Biochem. 31: 135-152.

Pickering, T.D., P. Skelton, Sulu, J.R., 2007. Intentional Introductions of Commercially Harvested Alien Seaweeds, Botani Marien. 50. 338-350.

Ra, C.H., Jeong, G.T., Shin, M.K., Kim, S.K., 2013. Biotransformation of 5hydroxymethylfurfural (HMF) by Scheffersomyces stipitis during ethanol fermentation of hydrolysate of the seaweed Gelidium amansii.Bioresour. Technol. 140: 421-425.

Ramachandran, V., Pujari, N., Matey, T., \& Kulkarni, S. 2013.Enzymatic Hydrolysis for Glucose-A Review. International Journal of Science, Engineering and Technology Research. 10(2): 1937-1942.

Ravanal, C., Salazar, O., Mäki-Arvela, P., Mikkola, J. P., Lienqueo M. E. 2016.Comparison of different types of pretreatment and enzymatic saccharification of Macrocystis pyrifera for the production of biofuel. Algal Res. 13: 141-7.

Sankh, S., Meikadhan Tinru, Saurabh, S., \&Vidyah, R., 2013. Biodiesel Production from a Newly Isolated Pichia kudriavzevii strai.. Industrial Biotechnology Group Reliance Life Science Put. Ltd. Nan Mumbai. India.

Vanegas, C.H., Hernon, A., Bartlett, J., 2015. Enzymatic and Organic Acid Pretreatment of Seaweed: Effect on Reducing Sugars Production and nn Biogas Inhibition. Int. J. Ambient Energy. 36, 2-7. 
Widodo, P., Chairul.S. and Reni, Y. Produksi Bioetanol Dari Nira Nipah Skala 50 Liter Dengan Penambahan Tween 80 Dan Ergosterol Pada Proses Fermentasi Menggunakan Saccharomyces Cerevisiae. 2015. JOM Teknik. 2:2. 1-8.

Wu, F.C., Wu, J.Y., Liao, Y.J., Wang, M.Y., Shih, I.L., 2014. Sequential acid andenzymatic hydrolysis in situ and bioethanol production from Gracilariabiomass.Bioresour. Technol. 156, 123-131. 